\title{
KINERJA LINGKUNGAN DAN KINERJA EKONOMI PERUSAHAAN MANUFAKTUR GO PUBLIC
}

\author{
Rutinaias Haholongan \\ Fakultas Ekonomi dan Bisnis, Ikpia Perbanas Jakarta \\ rutinaias@gmail.com
}

\begin{abstract}
Environmental performance is strongly influenced by the extent to which the impetus towards environmental management carried out by various agencies, especially government agencies. Firms are more likely to have better environmental performance if they proactively perform various controlled environmental management actions. This research aims to examine the influence of environmental performance on economic performance. We used data from 2009-2011 annual reports at the Indonesia Stock Exchange and PROPER. The results show that environmental performance has a significant effect on economic performance.
\end{abstract}

Keywords: Environmental Performance, Economic Performance.

\begin{abstract}
ABSTRAK
Kinerja lingkungan sangat dipengaruhi oleh sejauh mana dorongan terhadap pengelolaan lingkungan yang dilakukan oleh berbagai instansi khususnya instansi pemerintah. Kinerja lingkungan juga akan tercapai pada level yang tinggi jika perusahaan secara proaktif melakukan berbagai tindakan manajemen lingkungan secara terkendali. Tujuan dalam penelitian ini adalah menguji pengaruh kinerja lingkungan terhadap kinerja ekonomi. Data dianalisis dengan menggunakan regresi berganda. Data yang digunakan dalam penelitian ini berasal dari laporan tahunan yang terdaftar di Bursa Efek Indonesia dan PROPER pada tahun 2009-2011. Hasil penelitian ini menunjukkan bahwa kinerja lingkungan berpengaruh signifikan terhadap kinerja ekonomi.
\end{abstract}

Kata Kunci: kinerja lingkungan, kinerja ekonomi.

\section{PENDAHULUAN}

Eksistensi perusahaan di tengah lingkungan dan masyarakat berdampak positif maupun negatif. Dampak positif yang ditimbulkan antara lain keberadaan perusahaan ditengah lingkungan dan masyarakat seperti, menciptakan lapangan kerja, menyediakan barang yang dibutuhkan masyarakat untuk dikonsumsi, meningkatkan pendapatan, menyumbang pendapatan daerah dan negara, serta mendukung peningkatan ekonomi, dan lain-lain. Sementara, dampak negatif (negative externalities) antara lain keberadaan perusahaan di tengah lingkungan menimbulkan pencemaran baik tanah, air maupun udara. Hal tersebut mengancam 
munculnya polusi udara dan air, kebisingan suara, kemacetan lalu lintas, limbah kimia, hujan asam, radiasi, sampah nuklir, dan masih banyak lagi petaka lain sehingga menyebabkan stres mental dan kerugian fisik dalam kehidupan masyarakat sehari-hari. Kesalahan dalam alokasi sumber daya manusia dan alam yang dilakukan oleh perusahaan sebagai penyebab utama.

Kinerja ekonomi akan menjadi penilaian para stakeholders. Semakin baik para pelaku bisnis, maka tujuan perusahaan akan tercapai dengan sendirinya dan bisnisnya akan berjalan dalam koridor yang diharapkan. Perilaku kinerja ekonomi yang bersifat etis, yaitu dengan mewujudkan tanggung jawab sosial perusahaan. Implikasi dari pelanggaran terhadap prinsip-prinsip tersebut diantaranya adalah terbengkalainya pengelolaan lingkungan dan rendahnya tingkat kinerja lingkungan serta rendahnya minat perusahaan terhadap konservasi lingkungan (Ja'far \& Arifah 2006).

Apabila sumber daya yang dimanfaatkan berupa sumber daya alam yang dilaksanakan secara besar-besaran, maka akan terjadi perubahan ekosistem yang mendasar. Pemerintah melalui Kementrian Lingkungan Hidup bahkan telah membetuk program yang disebut dengan PROPER (Program Penilaian Peringkat Kinerja Perusahaan dalam Pengelolaan Lingkungan Hidup) sebagai bentuk penaatan lingkungan hidup perusahaan-perusahaan di Indonesia. Hal ini dilakukan dalam hal menilai kinerja lingkungan perusahaan dan memacu agar perusahaan semakin baik dalam usaha peduli terhadap lingkungan. Respon baik atas program PROPER sebagai penilaian kinerja lingkungan perusahaan terus meningkat.

Kinerja lingkungan adalah mekanisme bagi perusahaan untuk secara sukarela mengintegrasikan perhatian terhadap lingkungan ke dalam operasinya dan interaksinya dengan pemangku kepentingan, yang melebihi tanggung jawab organisasi di bidang hukum. Oleh karena itu, Kementerian Lingkungan Hidup (KLH) dengan Bank Indonesia yang ditandatangani pada tahun 2005, yang merupakan tindak lanjut dari Peraturan Bank Indonesia Nomor 7/2/PBI/2005 tentang penetapan peringkat kualitas aktiva bagi bank umum. PROPER diadakan agar dapat mengendalikan dampak lingkungan untuk meningkatkan peran perusahaan dalam program pelestarian lingkungan. Kinerja lingkungan perusahaan diukur dengan menggunakan warna, mulai dari yang terbaik emas, hijau, biru merah, hingga yang terburuk hitam untuk kemudian kemudian diumumkan secara rutin kepada masyarakat agar masyarakat dapat mengetahui tingkat penataan pengelolaan lingkungan pada perusahaan dengan hanya meihat warna yang ada Fitriani (2013).

Seiring dengan meningkatnya kesadaran dan kepekaan dari stakeholders perusahaan maka konsep tanggung jawab sosial muncul dan menjadi bagian yang tidak terpisahkan dengan kelangsungan hidup perusahaan di masa yang akan datang. Pemangku kepentingan yang dimaksud di antaranya adalah para 
shareholder, karyawan (buruh), pelanggan, komunitas lokal, pemerintah, lembaga swadaya masyarakat (LSM), dan lain sebagainya.

Beberapa hasil penelitian yang berkaitan dengan topik ini, di antaranya, penelitian Suratno dan Mutmainah (2006) memberi bukti empiris adamya pengaruh kinerja lingkungan terhadap kinerja ekonomi. Berbeda dengan penelitian Almilia dan Wijayanto (2007) menguji pengaruh kinerja lingkungan terhadap kinerja ekonomi pada perusahaan pertambangan, temuan empiris menunjukkan tidak adanya pengaruh signifikan. Temuan empiris yang inkonklusif tersebut, menjadi senjang penelitian yang diangkat dalam penelitian ini. Lingkup penelitian terdahulu yang membatasi pada perusahaan pertambangan, perlu dikembangkan pada skopa lain yaitu perusahaan manufaktur yang memiliki karakteristik menarik dalam kaitannya dengan kinerja lingkungan maupun kinerja ekonomi. Tujuan penelitian ini untuk menemukan bukti empiris mengenai pengaruh kinerja lingkungan terhadap kinerja ekonomi pada perusahaan manufaktur go public di Bursa Efek Indonesia. Hasil dari penelitian ini memberi kontribusi teoritis pada. Berbagai riset yang mempengaruhi suatu pertimbangan dalam pengambilan keputusan berinvestasi. Secara praktis, para praktisi di lingkup organisasi perlu memperhatikan kinerja lingkungan.

\section{KAJIAN PUSTAKA}

\section{Kinerja Ekonomi (Economic Performance)}

Kinerja ekonomi diungkapkan dalam laporan keuangan tahunan perusahaan. Pada era perekonomian pasar yang disertai dengan terwujudnya kondisi kinerja ekonomi yang baik, efisien dan membawa keuntungan besar bagi perusahaan tetapi juga perlu disertai adanya perilaku kinerja ekonomi berkualitas etis yaitu perwujudan tanggung jawab sosial perusahaan secara baik. Almilia dan Wijayanto (2007) menyatakan bahwa kinerja ekonomi adalah kinerja perusahaan-perusahaan secara relatif berubah dari tahun ke tahun dalam suatu industri yang sama yang ditandai dengan return tahunan perusahaan

Sutami (2011) mengemukakan faktor-faktor kinerja lingkungan berhubungan nonkeuangan seperti kinerja keuangan, harga saham, dan biaya modal. Keberhasilan pimpinan sebagai pengelola perusahaan dapat dilihat dari kinerja keuangan atau kinerja ekonominya yang ditunjukkan oleh jumlah penjualan, tenaga kerja, harta yang dimiliki dan analisis rasio, yang disajikan dalam laporan keuangan. Terdapat tiga pokok pikiran mengenai hubungan antara tanggung jawab sosial perusahaan dan kinerja ekonomi. Pertama, pokok pikiran yang menggambarkan kebijakan konvensional; berpendapat bahwa terdapat biaya tambahan yang signifikan dan akan menghilangkan peluang perolehan laba untuk melaksanakan tanggung jawab sosial, sehingga akan menurunkan profitabilita. Kedua, biaya tambahan khusus untuk melaksanakan tanggung jawab sosial akan menghasilkan dampak netral (balance) terhadap profitabilitas. Hal ini disebabkan tambahan biaya yang dikeluarkan akan 
tertutupi oleh keuntungan efisiensi yang ditimbulkan oleh pengeluaran biaya tersebut. Tiga, pokok pikiran yang memprediksikan bahwa tanggung jawab sosial perusahaan berdampak positif terhadap profitabilitas.

\section{Kinerja Lingkungan (Environmental Performance)}

Masalah lingkungan yang ditimbulkan dari kegiatan operasi perusahaan berupa perusakan lingkungan dari perusahaan seperti yang bergerak di bidang pertambangan, mendorong munculnya praktik akuntansi lingkungan sebagai alat pertanggungjawaban atau akuntabilitas publik atas usaha yang dilakukan perusahaan Sudjoko (2011). Usaha pelestarian lingkungan dikenal dengan kinerja lingkungan (Wahyudi \& Busyra 2011). Kinerja lingkungan adalah kinerja perusahaan untuk ikut andil dalam melestarikan lingkungan. Kinerja lingkungan dibuat dalam bentuk peringkat oleh suatu lembaga yang berkaitan dengan lingkungan hidup (Wibisono 2013). PROPER yang merupakan program pemeringkatan lingkungan dari Kementrian Lingkungan hidup misalnya, merupakan pemeringkatan berdasarkan kinerja lingkungan tiap-tiap perusahaan, agar bisa dibandingkan dan menjadi koreksi bagi perusahaan tersebut.

Suratno dan Mutmainah (2006) menyatakan bahwa kinerja lingkungan adalah mekanisme bagi perusahaan untuk secara sukarela mengintegrasikan perhatian terhadap lingkungan ke dalam operasinya dan interaksinya dengan stakeholders, yang melebihi tanggung jawab organisasi di bidang hukum. Perusahaan memberikan perhatian terhadap lingkungan sebagai wujud tanggung jawab dan kepedulian perusahaan terhadap lingkungan (Lako 2011). Masyarakat yang tinggal di sekitar perusahaan berkepentingan terhadap dampak sosial dan lingkungan yang berasal dari aktivitas perusahaan (Untung 2012). Adanya kesadaran perusahaan menetapkan kinerja lingkungan secara baik sebenarnya merupakan perwujudan sekaligus titik temu antara kepentingan pelaku etis perusahaan dan esensi strategi pembangunan berkelanjutan, yaitu dengan melalui langkah mengintegrasikan antara pembangunan ekonomi, sosial, kemasyarakatan dan lingkungan hidup.

Pengukuran terhadap kinerja lingkungan dengan melihat prestasi perusahaan mengikuti program PROPER yang merupakan salah satu upaya yang dilakukan oleh Kementerian Lingkungan Hidup (KLH) untuk mendorong penataan perusahaan dalam pengelolaan lingkungan hidup melalui instrumen informasi. Sistem peringkat kinerja PROPER mencakup pemeringkatan perusahaan dalam lima warna yang akan diberi skor secara berturut-turut dengan nilai tertinggi 5 untuk warna emas, 4 untuk warna hijau, 3 untuk warna biru, 2 untuk warna merah, dan nilai terendah 1 untuk warna hitam. Tabel 1, 2, 3, 4 dan 5 (Lampiran) menunjukkan indikator perusahaan yang menerima warna emas, hijau, biru, merah, hitam. 
Perusahaan akan diberi penilaian warna emas apabila perusahaan tersebut telah melakukan pengelolaan lingkungan lebih dari yang dipersyaratkan dan telah melakukan upaya 3R (Reduce, Reuse, Recycle), menerapkan sistem pengelolaan lingkungan yang berkesinambungan, serta melakukan upaya-upaya yang berguna bagi kepentingan masyarakat pada jangka panjang. Perusahaan akan diberikan warna hijau apabila telah melakukan pengelolaan lingkungan lebih dari yang dipersyaratkan, telah mempunyai sistem pengelolaan lingkungan, mempunyai hubungan yang baik dengan masyarakat, termasuk melakukan 3R (Reduce, Reuse, Recycle). Perusahaan akan diberikan warna biru apabila telah melakukan upaya pengelolaan lingkungan yang dipersyaratkan sesuai dengan ketentuan atau peraturan yang berlaku. Sedangkan biru minus apabila perusahaan melakukan upaya pengelolaan lingkungan, tetapi baru sebagian mencapai hasil yang sesuai dengan persyaratan sebagaimana diatur dalam peraturan perundang-undangan.

Perusahaan akan diberikan penilaian warna merah apabila melakukan upaya pengelolaan lingkungan, tetapi baru sebagian kecil mencapai hasil yang sesuai dengan persyaratan sebagaimana diatur dalam peraturan perundang-undangan. Perusahaaan diberikan penilaian warna hitam apabila belum melakukan upaya pengelolaan lingkungan berarti, secara sengaja tidak melakukan upaya pengelolaan lingkungan sebagaimana yang dipersyaratkan serta berpotensi mencemari lingkungan.

\section{Hubungan Kinerja Lingkungan dengan Kinerja Ekonomi}

Kinerja lingkungan yang diproksi dengan rating kinerja PROPER dalam lima kode warna rating dari mulai yang terbaik sampai perusahan dengn kinerja lingkungan terburuk yaitu: emas, hijau, biru, merah, hitam mempunyai pengaruh yang kuat terhadap kinerja ekonomi. Perusahaan yang memiliki kinerja lingkungan yang bagus akan direspon secara positif oleh para investor melalui fluktuasi harga saham perusahaan yang semakin naik dari perioda ke perioda. Sebaliknya, jika perusahaan dengan rating buruk maka akan muncul keraguan dari para investor terhadap perusahaan tersebut dan direspon negatif dengan fluktuasi harga sahamperusahaan dipasar yang semakin menurun dari tahun ke tahun. Begitu pula dengan pengungkapan lingkungan perusahaan manufaktur go public di Bursa Efek Indonesia yang dinilai sebagai perusahaan berisiko lingkungan yang tinggi.

Semakin besar peran perusahaan di dalam kegiatan lingkungan, maka semakin baik pula pencitraan perusahaan bagi para pemangku kepentingan. Dengan adanya pencitraan positif tersebut, maka akan dapat menarik perhatian dari para pemangku kepentingan maupun masyarakat pengguna laporan keuangan. Dengan kinerja lingkungan perusahaan yang meningkat akan semakin baik pula kinerja ekonomi perusahaan tersebut. Dampaknya adalah pasar akan merespon secara positif melalui fluktuasi harga saham yang diikuti oleh meningkatnya return saham perusahaan yang secara relatif merupakan cerminan pencapaian kinerja ekonomi. 
Perusahaan diharapkan tidak hanya mementingkan kepentingan manajemen dan pemilik modal (investor dan kreditor), tetapi juga karyawan, konsumen serta masyarakat. Perusahaan mempunyai tanggung jawab sosial terhadap pihak-pihak di luar manajemen dan pemilik modal. Namun demikian, perusahaan kadangkala melalaikannya dengan alasan bahwa mereka tidak memberikan kontribusi terhadap kelangsungan hidup perusahaan. Hal ini disebabkan hubungan perusahaan dengan lingkungan bersifat non reciprocal yaitu transaksi keduanya tidak menimbulkan prestasi timbal balik. Donovan dan Gibson (2000) menyatakan bahwa berdasarkan teori legitimasi, salah satu argumentasi dalam hubungan antara profitabilitas dan tingkat kinerja sosial adalah ketika perusahaan memiliki tingkat laba yang tinggi, perusahaan (manajemen) menganggap tidak perlu melaporkan hal-hal yang dapat mengganggu informasi tentang sukses keuangan perusahaan. Sebaliknya, pada saat tingkat profitabilitas rendah, mereka berharap para pengguna laporan akan membaca good news kinerja perusahaan, misalnya dalam lingkup sosial, dan dengan demikian investor akan tetap berinvestasi di perusahaan tersebut.

Semakin besar andil perusahaan di dalam kegiatan lingkungan, maka semakin baik pula pencitraanperusahaan bagi para pemangku kepentingan. Dewasa ini tuntutan terhadap perusahaan semakin besar. Perusahaan diharapkan tidak hanya mementingkan kepentingan manajemen dan pemilik modal (investor dan kreditor), tetapi juga karyawan, konsumen serta masyarakat. Perusahaan mempunyai tanggung jawab sosial terhadap pihak-pihak di luar manajemen dan pemilik modal. Perusahaan kadangkala melalaikannya dengan alasan bahwa mereka tidak memberikan kontribusi terhadap kelangsungan hidup perusahaan. Hal ini disebabkan hubungan perusahaan dengan lingkungan bersifat non reciprocal yaitu transaksi keduanya tidak menimbulkan prestasi timbal balik.

Hasil penelitian ini didukung oleh Susi (2005), Suratno dan Mutmainah, (2006) membuktikan bahwa terdapat pengaruh positif antara kinerja lingkungan terhadap kinerja ekonomi. Berdasarkan riset terdahulu dan argumentasi yang disusun maka dapat diusulkan hipotesis sebagai berikut.

H1: Terdapat pengaruh positif antara kinerja lingkungan terhadap kinerja ekonomi pada perusahaan manufaktur go public di BEI.

\section{METODA PENELITIAN}

Populasi dalam penelitian ini adalah seluruh perusahaan manufaktur yang go public yang sahamnya telah diperjual-belikan di Bursa Efek Indonesia. Pemilihan sampel pada populasi dipilih secara purposive sampling yaitu perusahaan manufaktur yang tercatat di Bursa Efek Indonesia yang mengikuti Program Peningkatan Kinerja Perusahaan dalam Pengelolaan Lingkungan Hidup (PROPER) pada tahun 2009 2011 dan telah menerbitkan laporan keuangan tahunan (annual report) pada tahun 2009-2011. Variabel bebas dalam penelitian ini adalah kinerja lingkungan, 
sedangkan variabel terikat adalah kinerja ekonomi perusahaan manufaktur yang go public di Bursa Efek Indonesia (BEI) tahun 2009-2011. Teknik analisis dengan menggunakan uji analisis regresi linear berganda.

\section{Definisi Operasional dan Pengukuran Variabel}

Kinerja ekonomi menurut Ikhsan (2012) merupakan kinerja perusahaan secara relatif dalam suatu industri sejenis yang ditandai dengan return tahunan industri yang bersangkutan. Tuwaijri (2004) menyatakan kinerja ekonomi dinyatakan dalam skala hitung berikut ini.

\begin{tabular}{|c|c|c|}
\hline \multicolumn{3}{|c|}{$P 0$} \\
\hline P1 & $=$ & Harga saham akhir tahun \\
\hline P0 & $=$ & Harga saham awal tahun \\
\hline $\mathrm{D}_{\mathrm{iv}}$ & $=$ & Pembagian deviden \\
\hline $\mathrm{Me}_{\mathrm{Ri}}$ & $=$ & Median return industri \\
\hline
\end{tabular}

Return industri diukur dari indeks industri yang diperoleh dari laporan Indonesian Stock Exchange (IDX). Indeks industri disesuaikan dengan sample dalam penelitian ini, karena penelitian ini menggunakan sampel perusahaan manufaktur, maka indeks industri yang digunakan adalah indeks industri manufaktur.

Kinerja lingkungan perusahaan adalah kinerja perusahaan dalam menciptakan lingkungan yang baik (green) (Welford 2010). Pengukuran kinerja lingkungan dengan melihat prestasi perusahaan mengikuti program PROPER yang merupakan salah satu upaya yang dilakukan oleh Kementerian Lingkungan Hidup (KLH) untuk mendorong penataan perusahaan dalam pengelolaan lingkungan hidup melalui instrumen informasi. Sistem peringkat kinerja PROPER mencakup pemeringkatan perusahaan dalam lima warna yang akandiberi skor secara berturut-turut dengan nilai tertinggi 5 untuk warna emas, 4 untuk warna hijau, 3 untuk warna biru, 2 untuk warna merah dan nilai terendah 1 untuk warna hitam, di mana setiap perusahaan berbeda-beda skor kinerja lingkungannya sesuai dengan peringkat yang ditetapkan oleh Kementerian Lingkungan Hidup (KLH).

\section{ANALISIS DAN PEMBAHASAN}

Hasil pengujian dengan regresi disajikan pada tabel 6. Dari hasil pengujian diperoleh hasil besarnya koefisien determinasi yang menunjukkan pengaruh kinerja lingkungan terhadap kinerja ekonomi yang dapat diterangkan oleh model persamaan ini adalah sebesar 58\%. Faktor lain seperti faktor ekonomi negara secara makro, faktor sentimen pasar serta faktor politik negara berpotensi mempengaruhi model regresi. Tingkat signifikansi hasil pengujian menunjukkan 0,002 $(<0,05)$ sehingga hipotesis penelitian terdukung. 
Tabel 6

Ringkasan Hasil Analisis Regresi

\begin{tabular}{lcccc}
\hline \multicolumn{1}{c}{ Keterangan } & B & Nilai t & F & Sig \\
\hline Kinerja Lingkungan & 2,643 & 5,814 & 27,814 & 0,002 \\
\hline 1. Koefisien determinasi & \multicolumn{5}{c}{0,582} \\
\hline
\end{tabular}

Hasil penelitian menunjukkan bahwa kinerja lingkungan perusahaan baik ataupun buruk berpengaruh terhadap kinerja ekonomi suatu perusahaan pada masa yang akan datang. Masyarakat hanya memandang kinerja lingkungan perusahaan pada periode yang sama dan akan menilai lagi terhadap kinerja lingkungan perusahaan masa yang akan datang dengan kinerja lingkungan.

Suratno (2006) mengatakan pelaku lingkungan yang baik percaya bahwa dengan mengungkapkan kinerja lingkungan berarti menggambarkan good news bagi pelaku pasar. Kinerja ekonomi yang baik mengurangi pengkungkapan biaya-biaya lingkungan masa depan perusahaan. Pengungkapan informasi biaya-biaya lingkungan ini harus dirasakan sebagai berita gembira oleh para investor Kinerja lingkungan sangat dipengaruhi oleh sejauh mana dorongan terhadap pengelolaan lingkungan yang dilakukan oleh berbagai instansi khususnya instansi pemerintah. Kinerja lingkungan juga akan tercapai pada level yang tinggi jika perusahaan secara proaktif melakukan berbagai tindakan manajemen lingkungan secara terkendali. Dengan adanya tindakan proaktif perusahaan dalam pengelolaan lingkungan serta adanya kinerja yang tinggi, manajemen perusahaan diharapkan akan mendorong pertumbuhan kinerja ekonomi yang baik.

Almilia dan Wijayanto (2007) menyatakan, implementasi riilnya kinerja lingkungan melalui pelaksanaan program corporate social responsibility dan mengungkapkannya baik di dalam annual report maupun sustainability report sebagai suatu bentuk informasi yang dibutuhkan investor untuk mengambil keputusan terkait kinerja perusahaan yang sesuai dengan nilai-nilai di dalam masyarakat

Di negara berkembang kinerja lingkungan, seperti Indonesia berpengaruh terhadap kinerja ekonomi. Perusahaan terutama yang melakukan kinerja lingkungan dengan turut berkontribusi secara aktif dalam menjaga kelestarian lingkungan berdampak pada kinerja ekonomi. Hal ini mengindikasikan masyarakat merespon baik kinerja lingkungan yang dijalankan oleh perusahaan, sehingga meningkatkan aktivitas ekonomi perusahaan. Di negara-negara maju, studi sebelumnya menunjukkan hasil yang beragam pada hubungan ini.

Temuan ini konsisten dengan temuan peneliti terdahulu yang dilakukan Susi (2005), kinerja lingkungan yang dilakukan perusahaan mempengaruhi kinerja ekonomi, Adanya perusahaan yang mengikuti program PROPER melaporkan atau mengikuti aturan dalam kinerja PROPER. Sehingga kinerja lingkungan perusahaan 
menjadi baik dan memenuhi kriterian kinerja lingkungan yang baik. Dengan kinerja lingkungan perusahaan yang baik tersebut menjadikan perusahaan berpeluang besar untuk memberikan pengungkapan mengenai kinerja lingkungannya

Ghozali dan Chariri (2011), perusahaan akan mengungkapkan semua informasi yang diperlukan dalam rangka berjalannya fungsi pasar modal. Pendukung pendapat tersebut menyatakan bahwa jika suatu informasi tidak diungkapkan hal ini disebabkan informasi tersebut tidak relevan bagi investor atau informasi tersebut telah tersedia di tempat lain.

Suratno dan Mutmainah (2006) membuktikan bahwa terdapat pengaruh positif antara kinerja lingkungan terhadap kinerja ekonomi. Semakin besar andil perusahaan di dalam kegiatan lingkungan, maka semakin baik pula image perusahaan di mata stakeholder maupun pengguna laporan keuangan. Dengan adanya image positif tersebut, maka akan dapat menarik perhatian dari para stakeholder maupun masyarakat pengguna laporan keuangan. Dengan kinerja lingkungan perusahaan yang meningkat akan semakin baik pula kinerja ekonomi perusahaan tersebut, sehingga pasar akan merespon secara positif melalui fluktuasi harga saham yang diikuti oleh meningkatnya return saham perusahaan yang secara relatif merupakan cerminan pencapaian economic performance.

\section{SIMPULAN, KETERBATASAN DAN SARAN}

Berdasarkan pada hasil analisis yang telah dilakukan, maka dapat ditarik kesimpulan kinerja lingkungan memiliki pengaruh positif terhadap kinerja ekonomiperusahaan manufaktur yang go public di Bursa Efek Indonesia tahun 20092011. Perusahaan diharapkan memperhatikan kelengkapan item-item pengungkapan environmental performance yang perlu diungkapkan dalam laporan berkelanjutan. Hal tersebut tentu akan mempermudah investor untuk menilai kinerja perusahaan. Di samping itu perlu adanya peraturan yang lebih mengikat dari pemerintah mengenai laporan berkelanjutan yang dilakukan perusahaan sehingga perusahaan dapat mengetahui lebih jelas mengenai informasi apa yang harus diungkapkan dalam laporan berkelanjutan.

\section{Keterbatasan Penelitian dan Saran}

Penelitian ini dilakukan terbatas pada periode pengamatan yang relatif pendek yaitu selama 3 tahun. Penelitian selanjutnya agar digunakan jenjang tahun penelitian yang lebih lama agar diperoleh hasil yang lebih detail tentang perusahaan sehingga bisa diketahui bahwa suatu perusahaan melakukan pengungkapan serta kinerja ekonomi dari perusahaan tersebut dilakukan secara berkesinambungan atau tidak di setiap tahunnya. 


\section{DAFTAR PUSTAKA}

Al-Tuwaijri, S. 2004. "The relations among environmental disclosure, environmental performance, and economic performance: a simultaneous equations approach." A Journal of Theory and Practice 29 (5-6): 447-71. https://doi.org/10.1016/S0361-3682(03)00032-1.

Almilia, Luciana Spica, dan Dwi Wijayanto. 2007. "Pengaruh environmental performance dan environmental disclosure terhadap economic performance." Proocedings The 1st Accounting Conference Depok, 1-23.

Fitriani, Anis. 2013. "Pengaruh kinerja lingkungan dan biaya lingkungan terhadap kinerja keuangan pada BUMN.” Jurnal Ilmu Manajemen 1 (1): 137-48.

Ghozali, Imam, dan Anis Chariri. 2011. Teori akuntansi. Semarang: Badan Penerbit Fakultas Ekonomi Universitas Diponegoro.

Ikhsan, Arfan. 2012. Akuntansi lingkungan. Yogyakarta: Graha Ilmu.

Ja'far, S, dan D.A. Arifah. 2006. "Pengaruh dorongan manajemen lingkungan, proaktif dan kinerja lingkungan publik environmental reporting. Prooceding SNA.” Prooceding SNA 9: 23-26.

Lako, Andreas. 2011. Dekonstruksi csr \& reformasi paradigma bisnis \& akuntansi. Jakarta: Erlangga.

Sudjoko. 2011. Pendidikan lingkungan hidup. Jakarta: Universitas Terbuka.

Suratno, Ignatius Bondan, dan Siti Mutmainah. 2006. "Pengaruh environmental performance terhadap environmental disclosure dan economic performance." Prooceding SNA 9 Padang 10 (2): : 1-20.

Susi, Sarumpaet. 2005. "The relationship between environmental performance and financial performance of Indonesian companies." Jurusan Akuntansi \& Kewangan 7 (2): 89-98.

Sutami, Eka, Ratna Anggraini, dan Adam Zakaria. 2011. "The effect of voluntary disclosure of environmental performance and level of externalitas to corporate economic performance." The 3rd International conference on humanities and social science april 2: 1-10.

Untung, Jendrik Budi. 2012. Corporate social responsibility. Jakkarta: Sinar Grafika.

Wahyudi, Isa, dan Azheri Busyra. 2011. Corporate social responsibility : prinsip, pengaturan dan implementasi. Malang: In-Trans Publishing.

Welford, Richard. 2010. Corporate environmental managemen. London: Eartscan Publication.

Wibisono, Yusuf. 2013. Membedah konsep \& aplikasi csr. Gresik: Fascho Publishing. 
